\title{
DETERMINANTS OF FOOD SECURITY AMONG FARMING HOUSEHOLDS IN AKURE NORTH LOCAL GOVERNMENT AREA OF ONDO STATE, NIGERIA
}

\author{
Haruna I. Opaluwa, ${ }^{*}$ Felix O. Oyibo, Fatai A. Jimoh
}

Department of Agricultural Economics \& Extension, Faculty of Agriculture, Kogi State University, Nigeria

*Corresponding author e-mail: harusopaluwa@gmail.com

Citation: Opaluwa, H.I., Oyibo, F.O., and Jimoh, F.A. 2018. Determinants of Food Security among Farming Households in Akure North Local Government Area of Ondo State, Nigeria. $J$. Asian Rur. Stud. 2(2): 164-172

\begin{abstract}
The determinants of food securityamong farming households in Akure North Local Government Area of Ondo State, Nigeria is the main focus of this study.It specifically described the socioeconomiccharacteristics of the farming households, analyzed the food security situation of the respondents and estimated the determinants of food security among the households in the study area. Structured questionnaire was used to collect data from 109farming householdswho were selected by a three stage random sampling technique. The collected data were analyzed using descriptive statistics, Food security index, FGT and Binary Logit regression model. Findings of the study showed a young vibrant farming population, relatively literate and engaged in small scale farming. The outcome of the study also indicated that majority (80percent) of the respondents were food insecure consuming less than the recommended daily calories intake of $2260 \mathrm{kcal}$. Food secure households in the study area exceeded the calorie requirement by $69 \%$ while the food insecure households fell short of the recommended calorie intake by $37 \%$. The result of the Logit regression revealed that education, household size, farm size and total household income were the statistically significant variables affecting the food security of the farming households in the study area. These coefficients have values of 1.490, $0.021,0.264$ and 0.000 respectively. It was recommended that Government should provide an integrated approach that promotes formal education among farming households to enhance their farm production activities. There is also a need to promote large scale farming in the area. It was further recommended that enlightenment programmes on nutrition and birth control measure should be directed at the farming households in the study area. This will help to check the consumption of unbalanced diets and uncontrolled child births respectively.
\end{abstract}

Keywords: Food; Security; Households; Ondo; State

\section{Introduction}

The importance of food in the productivity and development of a nation cannot be over emphasized because it is a basic necessity of life. Adequate food intake, in terms of quantity and quality isimportant for a healthy and productive life (NFSP, 2001). Kayunze, (2008) posited that various foods serve as important "vehicles" for taking nutrients into the body and bringing about human pleasure, hence, the need for food to be taken in the right quantity and quality. Consumption of food from the classes of essential nutrients assures quality (Oguntona and Akinyele, 1995). 
However, sufficiency in foodprovision is one of the challenges facing the society which is continual with the history of human civilization. This could be attributed to the increase in population as gathering food from nature is no longer feasible as in the old civilization. Food consumption and production has become a civilization problem and pose a threat to nature as population increases (Ali et al., 2017). There has been increase in global concern for food security most especially since the world food crisis of 197274 (Ajibola, 2000). Food security is referred to as the state of having secure and sustainable access to sufficient food for an active and healthy life (Maxwell and Wiebe, 1998).

The effect of food security differs at the global, national, household and individual levels. The Food security at global level does not guarantee food security at the national level; and food security at the national level does not guarantee food security at the household (Duffourk, 2011). The right to food is a fundamental human right given to man by his creator yet between 60- 70 percent of households are food insecure (Arene and Anyaeji, 2010; Orewa and Iyangbe, 2010; Olayemi, 2012;Omuemu et al., 2012).This may increase the vulnerability of households to malnutrition and health issues. Consequently, the food situation is getting worse as farms are being abandoned to the elderly for off-farm jobs, which income has not been proven to be adequate to meet households needs (Akinsanmi and Doppler, 2005).

Several Studies exist on the concept of food security (Babatunde et al, 2007; Idrisa, 2008; Orewa and Iyangbe, 2009; Obayelu,2010; Arene and Anyaeji, 2010; Omuemu et al,2012; Olayemi, 2012; Cornelius et al, 2015) However, few or none of these studies focused on the determinants of food security among farming households in Akure North LGA of Ondo State, Nigeria. It is against this background that this study intends to describe the socio-economic characteristics of the household, analyze the food security situation of the respondents and determine factors influencing food security among farming households in the study area.

\section{Methods}

This study was carried out in Akure North Local Government area of Ondo state, Nigeria. The Local Government is located in the Central senatorial district of Ondo State. Geographically, the local government is located between $5^{\circ} 22^{\prime} 14^{\prime \prime} \mathrm{N}$ and $6^{\circ} 37^{\prime} 31^{\prime \prime}$ E with an estimated land area of 15,911 square kilometers and about 185,596 inhabitants (Obayelu, 2010). The people of the area are predominantly farmers with keen interest in arable crops production and also engage in other economic activities like trading, hunting.

Population for this study comprised of all registered Agricultural Development Projects (ADPs) Contact farmers in Akure North Local Government Area of OndoState.A three stage random sampling technique was used to select the respondents for this study. The first stage involved random selection of five wards from the eleven wards in the local government area. The five wards selected are;Aiyedeogbese, Oba ile, Osi, Araromi and Ilu abo. Secondly, one communitywas randomly selected from each of the five selectedwards to give a total of five farming communities used for the study. In the third stage, 24 households were randomly selected from each of the selected communities making a total of 120 households. Structured questionnaire was administered to household heads. Although, 120 
questionnaires were administered only 109 were used for the analysis based on their correctness and appropriateness. The data obtained were analyzed through the use of descriptive statistics, food security index, FGT and Binary Logit regression model.

Food security index was used to classify households into either food secure or food insecure depending on which side of the line they fall. The food security line is the recommended daily per capita calorie intake of 2260 kilo calorie (FAO, 1996). A household whose daily per capita calorie intake is up to 2260 kilo calorie intake was regarded as food secure and those whose daily per capita calorie intake is below 2260 kilo calorie were regarded as food insecure. This approach has been used by Babatunde et al.(2007); Kuwornuet al, (2013) and Cornelius et al,(2015)

The food security line is given as:

$\mathrm{Zi}=\boldsymbol{Y} \boldsymbol{i} / \boldsymbol{R}$

Where:

$\mathrm{Z}_{\mathrm{i}}=$ food security status of ith farmers.

$\mathrm{Y}_{\mathrm{i}}=$ daily per capita calorie intake of ith farmers (Adjusted for by adult equivalent)

$\mathrm{R}=$ recommended per capita daily calorie intake (2260kilo calorie)

$Z_{i}=1$ for $Y_{i}$ greater than or equal to $R$

$Z_{i}=0$ for $Y_{i}$ less than $R$

Additionally, the FGT model was used to calculate the surplus/shortfall index of food security for the sampled households based on the food security line. These index measures the extent to which households are above or below the food security line.

Surplusindex $=\frac{1}{X}\left(\sum_{i=1}^{X} G i\right)=\frac{1}{X}\left(\sum_{i=1}^{X} \frac{Y i-R}{R}\right) \ldots \ldots(2)$

Where:

$\mathrm{X}=$ The number of food secured households

$\mathrm{Gi}=$ Per capita calorie intake surplus for ith household

$\mathrm{N}=$ Number of households in the sample

Shortfallindex $=\frac{1}{M}\left(\sum_{i=1}^{M} G i\right)=\frac{1}{M}\left(\sum_{i=1}^{M} \frac{Y i-R}{R}\right) \ldots \ldots(3)$

Where:

$\mathrm{M}=$ The number of food insecure households

$\mathrm{Gi}=$ Per capita calorie intake deficiency for ith household

$\mathrm{N}=$ Number of households in the sample

The determinant of food security status was evaluated using Logit regression model.

The logit model can be specified as follows:

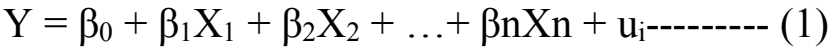


Where $\mathrm{Y}=$ is a binary variable defined as 1 if the household is food secure and 0 if the household in not food secure.

$\beta_{0}=$ constant

$\beta_{1}-\beta \mathrm{n}=$ Logistic regression coefficients

$\mathrm{X}_{1}-\mathrm{Xn}=$ Explanatory variables defined below;

$\mathrm{X}_{1}=\mathrm{Sex}:($ male $=1,0$ otherwise $)$

$\mathrm{X}_{2}=$ Marital status (married $=1,0$ otherwise)

$\mathrm{X}_{3}=$ Age (Years)

$\mathrm{X}_{4}=$ Educational level (number of years spent in schools)

$\mathrm{X}_{5}=$ Household size.(number of person)

$\mathrm{X}_{6}=$ Farm size (Hectares)

$\mathrm{X}_{7}=$ Cooperative membership (Yes $=1,0$ otherwise)

$\mathrm{X}_{8}=$ Total household income (Naira)

\section{Results and Discussion}

\subsection{Socioeconomic characteristics of the respondents}

The result of socioeconomic characteristics of the respondentsas presented on table 1 showed male dominance (79.8 percent) among the farming population in the area. It also shows that 80.7 percent of the respondents were married, indicating that family responsibilities might compete with farming activities thus negatively impacting food security. This could also suggest that more people would be available to work thereby increasing food production

Table 1 also indicated that majority ( 69.7 percent) of the respondent were within the active and vibrant productive age of $20-50$ years. This implies that the respondents have the ability to engage in agriculture and other activities that can facilitate the provision of food for their households.

Table 1. Distribution of Respondents According to Socioeconomic Characteristic

\begin{tabular}{lccc}
\hline Socio-economic indicators & Frequency & Percentage & Mean \\
\hline Sex & & & \\
Male & 87 & 79.8 \\
Female & 22 & 20.2 & \\
Total & 109 & 100 & \\
Marital status & & & \\
Married & 88 & 80.7 \\
Single & 13 & 11.9 \\
Divorced & 8 & 7.3 \\
Total & 109 & 100 \\
Age & & \\
20-30 & 14 & 12.8 \\
$31-40$ & 19 & 17.4 \\
$41-50$ & 43 & 39.5 \\
Above 51 & 33 & 30.2 \\
Total & 109 & 100 \\
Educational status & & \\
Non-formal education & 12 & 11.0
\end{tabular}




\begin{tabular}{|c|c|c|c|}
\hline Primary education & 33 & 30.3 & \\
\hline Secondary education & 51 & 46.8 & \\
\hline Tertiary education & 13 & 11.9 & \\
\hline Total & 109 & 100 & \\
\hline \multicolumn{4}{|l|}{ Household size } \\
\hline $1-5$ & 43 & 39.4 & \\
\hline $5-8$ & 60 & 55.0 & \\
\hline $9-12$ & 6 & 5.5 & \\
\hline Total & 109 & 100 & 7 persons \\
\hline \multicolumn{4}{|l|}{ Farm size } \\
\hline $0.1-0.5$ & 23 & 21.1 & \\
\hline $0.6-1.0$ & 50 & 45.9 & \\
\hline $1.1-1.5$ & 20 & 18.3 & \\
\hline $1.6-2.0$ & 9 & 8.3 & \\
\hline Above 2 & 7 & 6.4 & \\
\hline Total & 109 & 100 & \\
\hline \multicolumn{4}{|c|}{ Total household income } \\
\hline 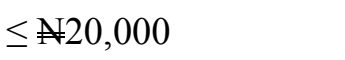 & 10 & 9.17 & \\
\hline$¥ 21,000-£ 60,000$ & 78 & 71.56 & \\
\hline$¥ 61,000-100,000$ & 20 & 18.35 & \\
\hline$>\$ 100,000$ & 1 & 0.92 & \\
\hline Total & 109 & 100 & 444663.3. \\
\hline
\end{tabular}

Source: field survey Data, 2016.

The result further showed that 89 percent of the respondents had one form of formal education or the other. This implies that the respondents will be able to take decision that will enhance the food security status of their household. Najafi (2003) posited that education enhances food security.

It can be deduced from table 1 that majority ( 55 percent) of the respondents had between 5-8 persons in their households. The average household size of the sample is 7 persons. This outcome has dual implications. The first implication is that large household size means more expenditure on food and other household expenses thereby threatening food security status of the households. The second implication is that there may be likely boast in food production of the household because large household size contributes to farm labour which is required to increase output thereby contributing to the household food security. Farming households in the study area still operate on a subsistence level. This is confirmed from table1 that majority (67 percent) of the respondents cultivated between 0.1-1 hectare. These plots are usually small and scattered with negative effect on output thus threatening food security

The average monthly per capita income for households head was $¥ 44663$.3. This translates to 1488.78 per day leading to an average income of 212.68 per person per day in the area. This is below the poverty line of $\$ 1$ per person per day because $\$ 1=$ $\$ 365$. The result showed that the respondents were living below poverty line. This result negates the findings of Babatunde et al. (2007). 


\subsection{Food Security Situation in Akure North LGA of Ondo State}

The result of the study on the food security situation in the study area as presented on Table 2 indicated that majority ( 80 percent) of the respondents in the study area were food insecure while only 20 percent were food secure. Furthermore based on the recommended daily calories intake $(\mathrm{R})$ of $2260 \mathrm{kcal}$, the headcount ratio shows that $20 \%$ of the households with an average daily per capita household calorie consumption of $3,823.02 \mathrm{kcal}$ were food secure and $80 \%$ of the households with average daily per capita calorie consumption $1,432.37 \mathrm{kcal}$ were food insecure.

Table 2. Distribution of the respondents Based on Food Security Situation in Akure North LGA of Ondo State

\begin{tabular}{lcc}
\hline Estimates & Food Secure & Food Insure \\
\hline Number of households & 22 & 87 \\
Percentage of households & 20.0 & 80.0 \\
Household average daily calorie consumption (Kcal) & $3,823.02$ & $1,432.37$ \\
Household maximum daily calorie consumption (Kcal) & $7,716.18$ & $2,432.36$ \\
Household minimum daily calorie consumption (Kcal) & $2,314.85$ & 777.16 \\
Surplus/shortfall index & 0.69 & 0.37 \\
\hline
\end{tabular}

Source: Computed from Field Survey Data, 2016

The surplus/ short fall index which measures the extent of deviation from the food security line showed that households had a surplus and short fall index of 0.69 and 0.37 respectively. This indicates that food secure households in the study area exceeded the calorie requirement by $69 \%$ while the food insecure households fell short of the recommended calorie intake by $37 \%$.

\subsection{Determinants of FoodSecurity among Farming Households in Akure North LGA of Ondo State}

The result of the Logit regression for the respondents as presented on Table 3 showed that education, farm size and household income positively affect food security status among the respondent while household size negatively affect it. Details are giving below.

The coefficient (1.490) of the level of education wasstatistically significant at 10 percent level and positively related to the household food security as showed in table 3 . This implies that an increase in the level of education of the respondents will lead to the likelihood of the household been food secure. This is in conformity with the a priori expectation. This result also agrees with the findings of Babatunde et al. (2007) who found education to be positively related with food security, and reported that households with more education are more food secure. 
Table 3. Logit Regression Estimates for the Determinants of Food Security among Farming Households in the Study Area

\begin{tabular}{lccc}
\hline Variable & $\begin{array}{c}\text { Regression } \\
\text { Coefficient }\end{array}$ & $\begin{array}{c}\text { Standard } \\
\text { Error }\end{array}$ & P. value \\
\hline Sex & 1.397 & 1.640 & 0.394 \\
Marital status & 0.107 & 1.106 & 0.923 \\
Age & -0.024 & 0.033 & 0.694 \\
Education & $1.490^{*}$ & 0.820 & 0.064 \\
Household size & $-0.021^{* *}$ & 0.161 & 0.043 \\
Farm size & $0.264^{* *}$ & 0.272 & 0.039 \\
Cooperative membership & 0.650 & 0.823 & 0.429 \\
Total household income & $0.000^{* * *}$ & 0.000 & 0.000 \\
Constant & -5.625 & 2.573 & 0.029 \\
\hline
\end{tabular}

$* * *=$ significant at $1 \% * *=$ significant at $5 \% *=$ significant at $10 \%$

Source: computed from field survey Data, 2016.

The result on Table 3 also showed that household size had a significant negative effect on food security. The coefficient $(-0.021)$ of this variable was significant at 1 percentlevel. This implies that the probability of food security decrease with an increase in the household size of the respondents. That is, large households size are more likely to be food insecure than small households size. This result is in conformity with that of Idrisa et al. (2008) who observed that the larger the household size, the more the increase in household expenses, especially, in a situation where majority of the household income is generated by the household heads.

Furthermore, it is evident from table 3 that farm size has a coefficient of (0.264)which is statistically significant at 5 percent level of significance and positively related to the food security of the farming households. This implies that the likelihood of households being food secure increases with an increase in farm size which usually reflect the output of the farmer. This result is consistent with Najafi (2003), who reported that food production can be increased extensively through expansion of areas under cultivation. With large farm size households can produce more than can enhance their food security.

Total household income had positive coefficient (0.000) which is statistically significant at 1 percent. This means that the higher the respondents household income, the higher the probability that the household would be food secure. This is because increased income would increase access to food. This is in conformity with Arene and Anyaeji (2010).Improved income has the potential to increase household's food security.

\section{Conclusion}

The outcome of this study revealed a young vibrant farming population with male dominance with majority of the respondents been married, with one form of formal education or the other. This study also indicated that majority of the respondents were food insecure consuming less than the recommended daily calories intake of $2260 \mathrm{kcal}$. Food secure households in the study area exceeded the calorie requirement by $69 \%$ while the food insecure households fell short of the recommended calorie intake by 
$37 \%$.It was further found out that thefood security situation of the farming households in the study area was determined by educational level, household size, farm size and total householdincome. It can be concluded from this study that increase in educational level, farm size, household income and decrease in household size have the potential to increase the number of food secure household in the study area. Considering these findings, Government should provide an integrated approach that promotes formal education as regard farm production activities among farming households to enhance their production activities thereby improving their food security status. It was further recommended that enlightenment programmes on nutrition and birth control measure should be directed at the farming households in the study area. This will help to check the consumption of unbalanced diets and uncontrolled child births respectively. Also there is need to promote commercial or large scale farming among the farming households in the state.

\section{References}

Ajibola, O. 2000. Institutional Analysis of the National Food Storage Programme Research Report, 23 Development Policy Centre, Ibadan

Akinsanmi, A. and W. Doppler (2005), "Socio-Economics and Food Security of Farming Families in South East Nigeria", Paper Presented at Tropentag, 2005 Conference on International Agricultural Research and Development, University of Hohenheim, Stuttgart, Germany.

Ali, M.S.S., Majika, A., Salman, D. 2017 Food consumption and production in Tempe Lake, South Sulawesi, Indonesia.J.AsianRur. Stud. 1(1): 43- 45

Amaza, P.S., T. Abdoulaye, P. Kwaghe, and A. Tegbaru. 2009. Changes in household food security and poverty status in PROSAB area of southern Borno State, Nigeria. IITA, Ibadan, Nigeria. 84 pp.

Arene, C. J. and Anyaeji, J. 2010.Determinants of Food Security among Households in Nsukka Metropolis of Enugu State, Nigeria.Pakistan Journal of Social Sciences 30(1): 9 - 16.

Babatunde, R. O., Omotosho, O. A. and Sholatan, O. S. 2007.Socio-economic Characteristics and Food Security of Farming Household in Kwara State, North Central Nigeria.Pakistan Journal of Nutrition 6(1):49-58.

Cornelius M.E., Kabiru U. and Oluwaseun A.O. 2015.Impact of Fadama III Project on the Food Security Status of Beneficiary and Non Beneficiary Farmers in Kabba/ Bunu LGA, Kogi State.Journal of Biology, Agriculture and Healthcare 5(24): 2228

Duffuor, k.,2011. Budget speech: Budget statement and policy of the Government of Ghana for the fiscal year 2011, minister of Finance and Economic Planning,Area, Ghana,pp:1-49

FAO, 2006.food and Agricultural Organisation, the state of food insecurity in the world,2005.Rome,pp:2

Idrisa, Y.L., Gwary. M.M. and Shehu H. 2008.Analysis of food security status among farming households in Jere Local Government of Bonro State, Nigeria. Journal of Tropical Agriculture, Food, Environment and Extension 7 (3): 199 - 205. 
Kayunze, K. A. 2008. HIV/AIDs and food security in Rufiji District Tanzania.Thesis for award of PhD degree at Sokoine University of Agriculture Morogoro, Tanzania. 258pp.

Kuwornu, J.K.M, Sulryman D.M and Amegashire D.P.K. 2013.Analysis of Food Security Status of Farming Households in the Forest Belt of the Central Region of Gahana.Russain Journal of Agriculture and Scio-Economic Science 1(13) pp 26-42.

Maxwell, D. and Wiebe, K. 1998.Land Tenure and Food Security: A Review of Concepts, Evidence and Methods, Research Paper No 129, Madison: University of Wisconsin.

Najafi, B. 2003.An Overview of Current Land Utilization Systems and Their Contribution to Agricultural Productivity.Report of the APO Seminar on Impact of Land Utilization Systems on Agricultural Productivity. Productivity Organization, Islamic Republic of Iran Asian.

NFSP (2001).Easy Route to Food Availability.Available at www.fao.org.

Obayelu, A. E. 2010. Classification of households into food security status in the NorthCentral Nigeria: An application of Rasch Measurement Model Journal of Agricultural and Biological Science 5 (3): 26 - 41.

Oguntona, E. B. and Akinyele, I. O. 1995.Nutrient Composition of Commonly Eaten Foods in Nigeria- Raw, Processed and Prepared.Food Basket Publication Series, Ibadan, Nigeria. P131.

Olayemi, A. O. (2012). Effects of family size on household food security inOsun State, Nigeria, Asian Journal of Agriculture and Rural Development2(2): 136-141.

Omuemu, V. O., Otasowie, E. M. and Onyiriuka, U. (2012). Prevalenceof food insecurity in Egor local government area of Edo State, Nigeria, Annals of African Medicine 11(3): 139-145.

Orewa, S. I. and C. O. Iyangbe. 2009. "Household Food Insecurity In Nigeria: An Assessment Of The Present Status Of Protein - Energy Malnutrition Among Rural And Low-Income Urban Households." Journal of Applied Sciences Research 5(10): 1615-1621.

Orewa, S. I. and Iyangbe, C. (2010). The struggle against hunger: the victims and the food security strategies adopted in adverse conditions, World Journal of Agricultural Sciences 6(6): 740-745.

Romuld, S. And Sandham, J. 1996. Gender issues and Farming Systems research and extension in Ethiopia, Proceedings of the international workshop.Institute of Agriculture Research, Addis Ababa, Ethiopia. 